\title{
Molecular study of Prussian carp - an invasive species in the lakes of the Leszno Lakeland
}

\author{
REMIGIUSZ PANICZ, ${ }^{1}$ SŁAWOMIR KESZKA, ${ }^{2}$ AGNIESZKA RYBCZYK, ${ }^{3}$ \\ ANDRZEJ ZAWAL ${ }^{4}$
}

\begin{abstract}
Department of Meat Sciences, Faculty of Food Sciences and Fisheries, West Pomeranian University of Technology Szczecin, 71-550 Szczecin, Kazimierza Królewicza 4, e-mail: rpanicz@zut.edu.pl

2 Department of Aquaculture, Faculty of Food Sciences and Fisheries, West Pomeranian University of Technology Szczecin, 71-550 Szczecin, Kazimierza Królewicza 4, e-mail: skeszka@zut.edu.pl

3 Department of Aquatic Sozology, West Pomeranian University of Technology, Kazimierza Królewicza 4, 71-550 Szczecin, Poland, e-mail: arybczyk@zut.edu.pl

4 Department of Invertebrate Zoology and Limnology, Institute for Research on Biodiversity, Faculty of Biology, Center of Molecular Biology and Biotechnology, University of Szczecin, 71-415 Szczecin, Wąska 13, Poland, e-mail: zawal@univ.szczecin.pl
\end{abstract}

Keywords Prussian carp, hotspot, invasive species, genetic variation

Abstract Invasions of alien species are a serious problem worldwide. In Poland, among of 30 alien species recorded in aquatic environment Prussian carp (Carassius gibelio) draw increasing attention due to its exceptionally successful colonization. Therefore the aim of the work was to perform study on Prussian carp populations, including genetic testing, which may answer questions regarding the degree of variation and the reasons for success in new locations. The material for the study consisted of fin clips from 120 specimens of the species Prussian carp collected from five lakes in the Leszno Lakeland. Genetic variation within and between groups was analysed based on sequence analysis of control region (D-loop, mtDNA). Genetic analyses revealed variability in sequence length (Indel 353A), where in the group of sequences from Lakes Wonieść and Łoniewskie there was one sequence variant, with 555 base pairs, but from Lakes Osłonińsko-Górskie, Dominickie and Wielkie, consisted of variants of 554 (30\%) and $555(70 \%)$ base pairs. Presented work indicate that presence and spread of alien species may be used as an indicator of worsening environmental conditions, therefore analysed areas should be given special attention in the process of restoration to their original state.

\section{Molekularne badania karasia srebrzystego - gatunku inwazyjnego w jeziorach Pojeziorza Leszczyńskiego}

Słowa kluczowe karaś srebrzysty, hot spot, gatunki inwazyjne, zróżnicowanie genetyczne

Streszczenie Inwazje gatunków obcych są ważnym problemem globalnym. Przykładowo oprócz 30 obcych gatunków ryb odnotowanych w polskich wodach, szczególną uwagę przyciąga karaś srebrzysty (Carassius gibelio) w związku z jego wyjątkowo ekspansywną strategią rozprzestrzeniania. $\mathrm{Z}$ tego też powodu celem niniejszego artykułu jest analiza populacji karasia srebrzystego, w tym testów genetycznych, które mogą udzielić odpowiedzi na pytanie o stopniu zróżnicowania i przyczynach sukcesu obserwowanych w kolejnych lokalizacjach. Materiał do badań 
stanowiły skrawki płetw 120 osobników karasia srebrzystego, które odłowiono w latach 2009 i 2010 z pięciu jezior należących do obszaru Pojezierza Leszczyńskiego. Analizy genetyczne w obrębie jak i pomiędzy grupami przeprowadzono na podstawie amplifikacji oraz analizy odczytanej sekwencji regionu kontrolnego (D-loop, mtDNA). Analiza uzyskanych sekwencji ujawniła, że różnią się one długością (Indel 353A). W grupie sekwencji z jezior Wonieść oraz Łoniewskie występował jedynie jeden wariant sekwencji, 555 par zasad. Pozostałe sekwencje uzyskane na bazie prób pozyskanych z jezior Osłonińsko-Górskie, Dominickie oraz Wielkie składały się z wariantów o długości 554 (30\%) i 555 (70\%) par zasad. Wyniki badań dowodzą, że obecność oraz rozprzestrzenianie się obcych gatunków może wskazywać na pogarszający się stan środowiska wodnego, dlatego rozpatrywane akweny należy traktować indywidualnie podczas prób przywracania ich do stanu pierwotnego.

\section{Introduction}

Invasions of alien species are a serious problem worldwide. According to the International Union for Conservation of Nature and Natural Resources (IUCN), they are one of the most significant threats to biodiversity, due to the unforeseen consequences of the appearance of a new species in the environment. In Polish waters, for example, about 30 alien fish species have been introduced the last 800 years (Grabowska et al. 2008). One of these, Prussian carp (Carassius gibelio), arrived in the natural waters of Europe at the beginning of the 20th century, probably after escaping from rearing ponds. The species is currently widely settled in Europe, as well as in northern and eastern Asia.

The Prussian carp probably appeared due to the importation of carp stocking material containing members of this species. According to the latest data from the Inland Fisheries Institute in Olsztyn, the catch of this species accounts for about 3.9\% of the total weight of caught fish (Wołos et al. 2014). Prussian carp can currently be considered the most abundant alien fish species in Poland (Grabowska et al. 2008). Prussian carp owes its exceptionally successful colonization to an efficient reproductive strategy (including high fertility and a long reproductive period), an opportunistic feeding strategy, and exceptional tolerance for difficult environmental conditions. The lakes of Leszno Lakeland (Pojezierze Leszczyńskie) have become a distinctive 'hotspot' (Rahel, Olden 2008) for the spread of Prussian carp. Studies on invasive species at such sites, including genetic testing, may answer questions regarding the degree of variation and the reasons for success in new locations.

\section{Study region}

The Leszno Lakeland, according to the division by Kondracki (1964), is a macroregion with an area of $2,227 \mathrm{~km}^{2}$ in the southern part of the Southern Baltic Lake District. Its location in the site of the last glaciation has resulted in a varied surface and relatively recent postglacial forms. The accumulation of stretches of terminal moraines and tunnel-valley lakes adds to the attractiveness of the landscape in terms of both tourism and fishing. The northern part of the Leszno Lakeland has been called the Kościan Plain. This area, at an elevation of 65-90 m a.s.1., has no lakes and is characterized by wide, peaty valleys. The Krzywiń Lakeland, with varied terrain, is situated a bit further south. In the eastern part of the region there are over 20 lakes with an area of more than 1 ha, scattered picturesquely among the hills. The western part, with somewhat less undulating terrain, has only one lake, Krzyckie. The lowest situated Sława Lakeland lies to the west, with the largest lakes. The southern boundary of the region is a distinct stretch of terminal moraines with numerous hills reaching up to $120 \mathrm{~m}$ a.s.l. (Anders 1985). 
The lakes in the Leszno Lakeland (Fig. 1) appear mainly in two clusters: the Sława and Krzywiń Lakelands. Most of these have an elongated shape dictated by the tunnel valleys. The largest of these are Lake Sława (817 ha), Wonieść (an artificial reservoir with an area of 777 ha), Dominickie (344 ha), Przemęckie Północne (243 ha), Wieleńskie-Trzytoniowe (220 ha), Cichowo-Mórka (201 ha), Zbęchy (108.9 ha) and Łoniewskie (102 ha).

Five of these lakes, presented in Table 1, were selected for the study. In the last 20 years these lakes have been stocked with Prussian carp and net fishing takes place here.

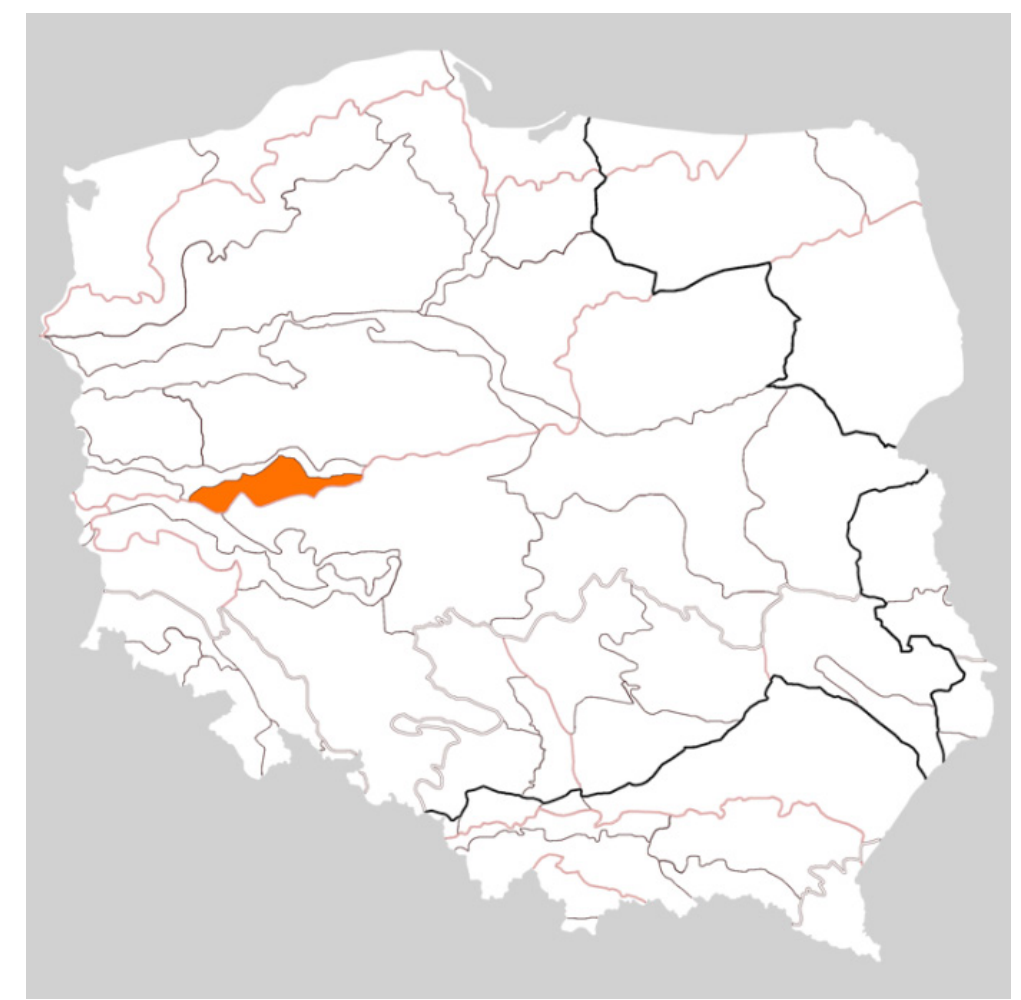

Figure 1. Location of the Leszno Lakeland

\section{Material and methods}

The material for the study consisted of fin clips from 120 specimens of the species Prussian carp (Carassius gibelio), caught in 2009 and 2010. The specimens were taken from five lakes in the Leszno Lakeland. Characteristics of the specimens and the sites where they were caught are presented in Table 1.

The samples were preserved in $75 \% \mathrm{EtOH}$ and transported to the laboratory of the Department of Aquaculture of the West Pomeranian University of Technology in Szczecin, where peqGOLD Tissue DNA Kits (PeqLab) were used to isolate DNA. Qualitative and quantitative evaluation of the isolates was performed by separation in $1.5 \%$ agarose gel and measurement using a NanoDrop 2000 spectrophotometer (Thermo Scientific). Genetic variation within and between 
groups was analysed by PCR, using the primers CYTB-1 5'-TAACGTTCCGCCCAATCAC-3' and DL-3 5'-CTACATTAATATGTTTGAATAAAA-3', which were designed to amplify the 5' end of the control region (D-loop) of mitochondrial DNA (Wouters et al. 2012). The compositions of the PCR mixtures and time/temperature profiles were in accordance with the information published by the authors. PCR products were sequenced by Genomed (Warsaw, Poland). The sequences were analysed using BLAST, BioEdit and DNA SP software (Altschul et al. 1990; Hall 1999; Librado, Rozas 2009).

Table 1. Characteristics of the lakes and samples used in the study

\begin{tabular}{|c|c|c|c|c|c|}
\hline Name of lake & Designation & GPS coordinates & $\begin{array}{c}\text { Number } \\
\text { of individuals } \\
\text { caught }\end{array}$ & $\begin{array}{c}\text { Mean } \\
\text { Length } \\
(\check{X}, \mathrm{SD})\end{array}$ & $\begin{array}{c}\text { Mean } \\
\text { Weight } \\
(\hat{X}, S D)\end{array}$ \\
\hline Łoniewskie & $\mathrm{LO}$ & $\begin{array}{l}51^{\circ} 53^{\prime} 58^{\prime \prime} \mathrm{N} \\
16^{\circ} 41^{\prime} 37^{\prime \prime} \mathrm{E}\end{array}$ & 22 & $26.35,3.22$ & $\begin{array}{l}728.5 \\
335.38\end{array}$ \\
\hline Wonieść & WO & $\begin{array}{c}52^{\circ} 00^{\prime} 19^{\prime \prime} \mathrm{N} \\
16^{\circ} 41^{\prime} 43^{\prime \prime} \mathrm{E}\end{array}$ & 28 & $26.31,2.83$ & $\begin{array}{l}710.93 \\
249.34\end{array}$ \\
\hline $\begin{array}{l}\text { Osłonińskie- } \\
\text { Górskie }\end{array}$ & OG & $\begin{array}{c}51^{\circ} 56^{\prime} 44.8^{\prime \prime} \mathrm{N} \\
16^{\circ} 14^{\prime} 19.3 \text { '” }\end{array}$ & 13 & 27.973 .88 & $\begin{array}{l}864.15 ; \\
423.11\end{array}$ \\
\hline Dominickie & DO & $\begin{array}{c}51^{\circ} 57^{\prime} 00^{\prime \prime} \mathrm{N} \\
16^{\circ} 18^{\prime} 36^{\prime \prime} \mathrm{E}\end{array}$ & 27 & 27.453 .06 & $\begin{array}{l}807.78 \\
315.55\end{array}$ \\
\hline Wielkie & WL & $\begin{array}{l}51^{\circ} 58^{\prime} 20.6^{\prime \prime} \mathrm{N} \\
16^{\circ} 20^{\prime} 24.2^{\prime \prime} \mathrm{E}\end{array}$ & 30 & 24.963 .10 & $\begin{array}{l}624.64 ; \\
199.59\end{array}$ \\
\hline
\end{tabular}

\section{Results}

The isolates obtained had concentrations of about $100 \mathrm{ng} / \mu \mathrm{l}$ and purity (260/280 ratio) ranging from 1.8 to 2.0. Analysis of the sequences obtained using the primers CYTB-1 and DL-3 revealed that the sequences differed in the number of bases: 554 or 555 base pairs (Indel 353A). In the group of sequences from Lakes Wonieść and Łoniewskie there was one sequence variant, with 555 base pairs. The remaining sequences, from the samples collected from Lakes OsłonińskoGórskie, Dominickie and Wielkie, consisted of variants of 554 (30\%) and 555 (70\%) base pairs. Except of abovementioned indel polymorphism, no other differences were found among the analysed sequences. The results of comparative analyses using both sequence variants indicated no homologous sequences in the NCBI database. BLAST search identified only one sequence of $C$. gibelio from China with full query coverage which shoved $97 \%$ similarity. The sequences obtained in the present study were submitted to the NCBI database with the deletion KP742348.1 and the insertion KP742349.1 (Fig. 2). 


\begin{tabular}{|c|c|c|c|c|c|c|}
\hline & 20 & 30 & 40 & 50 & 60 & \\
\hline $\begin{array}{l}\ldots \mid \ldots . \\
\text { САATTCCTA }\end{array}$ & $\begin{array}{l}\ldots \ldots|\ldots \ldots| \\
\text { TTTTGAACTC }\end{array}$ & $\begin{array}{c}\ldots|\ldots \ldots| \\
\text { TAGTCGCAGA }\end{array}$ & $\begin{array}{c}\ldots \ldots|\ldots| \\
\text { CATGATTATC }\end{array}$ & $\ldots \ldots|\ldots|$. & $\begin{array}{c}\ldots|\ldots| \ldots \mid \\
\text { TTGGAGGAAT }\end{array}$ & $\underset{A C C A G T A G A}{.}$ \\
\hline АATTCCTA & TTTGAACTC & TAGTCGCAGA & TTATC & AATGAA & $\mathrm{AAT}$ & GTAGAA \\
\hline & & & $\star \star \star \star \star ~$ & & & \\
\hline 80 & 90 & 100 & 110 & 120 & 130 & 140 \\
\hline$\ldots|\ldots|$ & $\ldots|\ldots|$ & $\ldots|\ldots|$ & $|\ldots|$ & $\ldots|\ldots|$ & $\cdot|\ldots|$. &.$|\ldots|$. \\
\hline САТССАТТСА & TTATCATCGG & ACAAATCGCA & GTCCTAT & АTTTCGCACT & СTTGTT & TCCCAC \\
\hline CATCCATTCA & TTATCATCGG & ACAAATCGCA & TCCGTCCTAT & ATTTCGCACT & GTTCCTTGTT & ГТСССАС \\
\hline 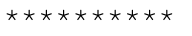 & 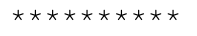 & 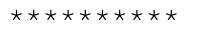 & 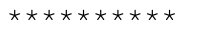 & 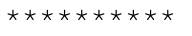 & 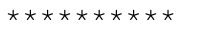 & 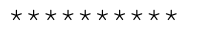 \\
\hline 150 & $0 \quad 160$ & 170 & 180 & 190 & 200 & 210 \\
\hline $\begin{array}{c}\ldots . \\
\Gamma A G C A G G T T G\end{array}$ & $\begin{array}{c}\ldots \\
\text { ATTAGAAAAT }\end{array}$ & $\begin{array}{c}\ldots \\
\text { AAAGCACTGA }\end{array}$ & $\begin{array}{c}\ldots \ldots \mid \ldots \\
\text { AATGAGCTTG }\end{array}$ & $\begin{array}{c}\ldots|\ldots| \cdots \mid \\
\text { CCCTAGTAGC }\end{array}$ & $\begin{array}{l}\cdots \\
\text { TTAGTATAAA }\end{array}$ & $\begin{array}{l}.|\ldots .| \\
\text { ATCGGTC }\end{array}$ \\
\hline GGTTG & ATTAGAAAAT & CACTGA & GCTTG & AGC & $\mathrm{AAA}$ & TCGGTC \\
\hline & & & & & & \\
\hline 220 & $0 \quad 230$ & 240 & 250 & 260 & 270 & 28 \\
\hline$\ldots|\ldots|$ & $\ldots|\ldots|$ & $\ldots|\ldots|$ & $|\ldots|$. & $\ldots \ldots|\ldots|$ & $\ldots 1$ &.$|\ldots|$. \\
\hline TTGTAATCCG & AAGATCGGAG & GTTAAATTCC & TAGCGC & AGA & TAA & CACCCC \\
\hline AATCCG & AAGATCGGAG & AATTCC & TAGCGC & $A G A$ & TTTTAA & $\mathrm{CACCCC}$ \\
\hline & & & & & 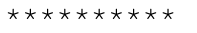 & 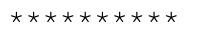 \\
\hline 290 & 300 & 310 & 320 & 330 & 340 & 350 \\
\hline$\ldots|\ldots|$ & $\ldots|\ldots|$ & $\ldots|\ldots|$ & $|\ldots|$ & $\ldots|\ldots|$ &.$|\ldots|$ &.$|\ldots|$. \\
\hline TGGCTCCCAA & AGCCAGAATT & СТАAАСТАAА & AтTTтстG & GGGATAACCA & ATG & CACA \\
\hline TGGCTCCCAA & AGCCAGAATT & ААСТАAА & TTTTCTG & $\mathrm{CCA}$ & ATG & $\Gamma A C A$ \\
\hline & & & & & $\star \star \star$ & \\
\hline 360 & $0 \quad 370$ & 380 & $\quad 390$ & 400 & 410 & 420 \\
\hline $\begin{array}{l}\ldots \downarrow \cdot \mid \ldots . .1 \\
\text { TA-TATGCAT }\end{array}$ & $\ddot{\ldots}|\ldots \ldots|$ & $\begin{array}{c}\ldots . \mid \ldots \\
\text { TAATGCATTA }\end{array}$ & $\begin{array}{c}\ldots \\
\text { GTACATATAT }\end{array}$ & GTATTATCAC & $\begin{array}{c}\ldots . \cdots \\
\text { CATATCATTA }\end{array}$ & $\begin{array}{c}\ldots|\ldots| \ldots \mid \\
\text { TTTTAACCCC }\end{array}$ \\
\hline TAATATGCAT & AATATTACAT & TTA & GTACATATAT & CAC & TTA & $\mathrm{CCCC}$ \\
\hline & (5) & & & 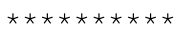 & & 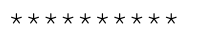 \\
\hline 430 & 440 & 450 & 460 & 470 & 480 & 490 \\
\hline$\ldots|\ldots|$ & $\ldots|\ldots|$ & &.$|\ldots|$. & $\cdots 1$ & $\ldots 1$ & \\
\hline AAAGCAAGTA & CATGTAAATT & AAGGTA & $\mathrm{TA}$ & $\mathrm{ACT}$ & TAA & TTTTGA \\
\hline AAAGCAAGTA & CATGTAAATT & AAGGTATACA & TAAAGCATAA & TCTTAAGACT & CACAAGTTAA & АтTATTTTGA \\
\hline 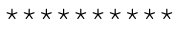 & 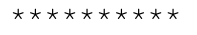 & 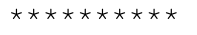 & 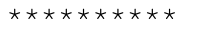 & 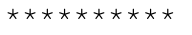 & 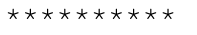 & 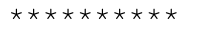 \\
\hline 500 & $0 \quad 510$ & 520 & 530 & 540 & 550 & \\
\hline$\ldots|\ldots|$ & $\ldots|\ldots|$ &.$|\ldots|$. & & & $\ldots 1$ & \\
\hline CCCGGGTAAT & АТАТTATTCС & AGAAATT & GTCCTCACAT & СТTTССTTGA & CAAC & \\
\hline CCCGGGTAAT & АТАТTATTCС & CCAAGAAATT & GTCCTCACAT & CTTTCCTTGA & ATGACTCAAC & TAAGG \\
\hline 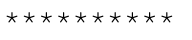 & & 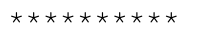 & & 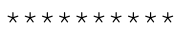 & & \\
\hline
\end{tabular}

Figure 2. Sequences obtained with marked insertion/deletion polymorphism at position 353 .

\section{Discussion}

Biological invasions by introduced alien organisms are widely considered more likely to succeed in environments disturbed by human activity (Case 1996; Lozon, Maclsaac 1997).

Introduced fish species may have a direct impact on native species through predation, competition for resources and habitats, an effect on reproduction, and the introduction of pathogens - parasites and diseases (Crowl et al. 1992).

Prussian carp has been found all over Poland since 1900 (Gąsowska 1936). Its invasion has included ponds, eutrophic lakes, small water bodies, channels, and lowland rivers. It is tolerant of oxygen shortages and high levels of contaminants. In particular it competes for food resources and habitats with limnophilous cyprinids (Solarz 2005). In the Danube River basin it 
competes strongly for food and habitats with native populations of Carassius carassius, Tinca tinca, Leucaspius deliniatus and other native cyprinids, reducing their populations. According to Lusk et al. (2010), it is currently the most dominant fish species in lentic and slow-flowing river habitats. In the lakes studied in the Leszno Lakeland the percentage of this species reaches up to $60 \%$ of the total weight of fish, about eleven times higher than the average for Poland; moreover, following the introduction of this species the structure of the ichthyofauna of individual water bodies became modified (Rybczyk, Szypuła 2005).

Identification of the original range of Carassius gibelio is most likely no longer possible (Grabowska et al. 2008). Reports of the occurrence of carp morphologically similar to C. gibelio in Europe date from the 16th century, and for this reason it is sometimes considered indigenous to the continent (Hensel 1971; Kottelat 1997). However, it is most likely an Asian species, as indicated by the close phylogenetic relationship (demonstrated by analysis of mitochondrial DNA) between European and Far Eastern individuals (Kalous, Šlechtová 2004). Loss and degradation of native biodiversity caused by alien species may occur at all levels of biological organization-genetic, population, species, community and ecosystem-and may entail significant changes in the physical environment, water quality, basic resources, and ecological processes (Mooney and Hobbs, 2000; Reise et al. 2006).

Researchers usually lack the information and knowledge to anticipate the consequences of the loss of specific adaptations caused by a loss of genetic diversity, but the relocation of certain organisms from one area to another, as seen in examples involving invertebrates, may entail the introduction of alien genes (Nehring et al. 2009).

Genetic screening will be necessary in the future to determine the degree of globalization that has been reached, and then to detect new invasive taxa or genotypes (Nehring et al. 2009). In the present study on Prussian carp, apart from insertion/deletion polymorphism no other differences were noted in the sequences analysed. Moreover, the results of comparative analyses using both of their variants indicated no homologous sequences in the NCBI database. The changes observed in the sequences may suggest a lack of isolation mechanisms and thus the spread of the most numerous genetic variant over the entire lake district. Kempter et al. (2011) reported even more pronounced homogeneity in three populations of the native species Carassius carassius. Phylogenetic analysis of the sequences of Prussian carp from Sweden showed that these fish are probably not native populations, but represent different lines of $C$. gibelio - from China, Japan and Russia. All but three of 16 fish analysed had microsatellite alleles suggesting hybridization with Carassius carassius. These results suggest that a cryptic invasion by C. gibelio may be taking place in Sweden (Wouters et al. 2012). The native C. carassius is a species whose protected status in Poland has recently been changed to 'near-threatened' (NT) (Witkowski et al. 2009). Considering the smaller scale of the invasion in Scandinavia, it is very likely that in Poland as well the populations of the two carp species hybridize, but in the present study no traces of hybridization were found. It is also highly likely that the success of Prussian carp as compared to the crucian carp is due to the greater genetic variation of the invasive species and to the native species' loss of alleles responsible for adaptation to a changing environment, resulting from artificial reproduction in aquaculture (Kempter et al. 2011). Furthermore, C. gibelio is able utilize a wider food spectrum and assimilate more nutrients in periods that are unconducive to feeding (Specziár, Rezsu 2009). A study on the composition of the food of C. gibelio colonizing waters in Turkey showed that it occupies the lowest trophic position of all species analysed, including native ones. Due to the high trophic position of vertebrates, they are generally more vulnerable to anthropogenic threats (Duffy 2003), C. gibelio may have a somewhat lower risk 
than other species of the ichthyocoenosis, and this may contribute to the success of its invasion (Özdilek, Jones 2014).

The progress of the invasion of Prussian carp has not been continually monitored in Poland, but studies on the ichthyofauna of Poland have drawn attention to the increasing presence of the species in Polish waters (Grabowska et al. 2008). The lakes of the Leszno Lakeland have become a distinctive 'hotspot' for the spread of Prussian carp due to its abundance and biological characteristics (Rybczyk, Szypuła 2005; Rybczyk 2006). The results of comparative analyses using both sequence variants in samples from the lakes of the Leszno Lakeland indicated no identical records in the NCBI database, which may suggest the existence of local haplotypes. Knowledge of the specific genetic character of the Prussian carp population in this lake district will make it possible to track the progress of invasion in nearby water bodies. Research conducted in the flowing waters of Australia has shown that aquatic ecosystems affected and modified by human activity are much more vulnerable to invasions by alien species (Kennard et al. 2005). The presence of alien species may therefore be used as an indicator of worsening environmental conditions, and these areas should be given special attention in the process of restoration to their original state (Kennard et al. 2005). Genetic screening may expand the possibilities for detection of unfavourable phenomena in monitored habitats.

\section{References}

Altschul S.F., Gish W., Miller W., Myers E.W., Lipman D.J., 1990. Basic local alignment search tool. J. Mol. Biol., 215: 403-410.

Anders P. 1985. Pojezierze Leszczyńskie. Wyd. PTTK, Warszawa.

Case T.J. 1996. Global patterns in the establishment and distribution of exotic birds. Biological Conservation, 8: 69-96.

Crowl T.A., Townsend C.R., McIntosh A.R. 1992. The impact of introduced brown and rainbow trout on native fish: the case of Australasia. Reviews in Fish Biology and Fisheries, 2: 217-241.

Duffy J.E., 2003. Biodiversity loss, trophic skew and ecosystem functioning. Ecology Letters, 6 (8): 680-687.

Gąsowska M. 1936. Der Giebel - eine ostasiatische Silberkarausche (Carassius auratus gibelio Bloch). Neue Unterscheidungsmerkmale. Zeitschrift fuer Fischerei und deren Hilfwissenschften Bnd, 34: 719-725.

Grabowska J., Witkowski A., Kotusz J. 2008. Inwazyjne gatunki ryb w polskich Wdach - zagrożenie dla rodzimej ichtiofauny. Użytkownik rybacki - nowa rzeczywistość. PZW, Warszawa, pp. 90-96.

Hall T.A. 1999. BioEdit: a user-friendly biological sequence alignment editor and analysis program for Windows 95/98/NT. Nucleic Acids Symp Ser., 41: 95-98.

Hensel K. 1971. Some notes on the systematic status of Carassius auratus gibelio (Bloch 1782) with further record of this fish from the Danube River in Czechoslovakia. Vestnik Československej Společnosti Zoologickej, 35: 186-198.

Kalous L., Šlechtová V. 2004. Carassius gibelio Autochthonous or Exotic Species in Europe: Molecular Phylogenetic Evidence. Proceedings of XI European Congress of Ichthyology, Tallinn, Estonia, September 6-10, p. 122.

Kempter J., Panicz R., Makowska M., Metza M., Keszka S., Kiełpiński M., Sadowski J. 2011. PCR-RFLP - based molecular studies on cytochrome b variability in the Crucian carp (Carassius carassius L.). Acta Biologica, 18: 5-15.

Kennard M.J., Arthington A.H., Pusey B.J., Harch B.D. 2005. Are alien fish a reliable indicator of river health? Freshwater Biology, 50: 174-193. DOI:10.1111/j.1365-2427.2004.01293.x. 
Kondracki J. 1964. Regiony fizycznogeograficzne Polski. Poznaj Świat XII, 4 (137).

Kottelat M. 1997. European freshwater fishes. Biologia (Bratislava), 52 (Suppl. 5): 1-271.

Librado P., Rozas J. 2009. DnaSP v5: A software for comprehensive analysis of DNA polymorphism data. Bioinformatics, 25: 1451-1452.

Lozon J.D., MacIsaac H.J. 1997. Biological invasions: are they dependent on disturbance? Environmental Reviews, 5: 131-144.

Lusk M.R., Luskova V., L. Hanel. 2010. Alien fish species in the Czech Republic and their impact on the native fish fauna. Folia Zoologica, 59: 57-72.

Mooney H.A., Hobbs R.J. (eds.) 2000. Invasive species in a changing world. Island Press, Washinton, p. 457.

Nehring S., Reise K., Dankers N., Kristensen P.S., 2009. Alien Species. Quality Status Report 2009. Wadden Sea Ecosystem, 25. Thematic Report No. 7.

Özdilek Ş.Y., Jones R.I. 2014. The Diet Composition and Trophic Position of Introduced Prussian Carp Carassius gibelio (Bloch, 1782) and Native Fish Species in a Turkish River. Turkish Journal of Fisheries and Aquatic Sciences, 14: 769-776. DOI: 10.4194/1303-2712-v14_3_19.

Rahel F.J., Olden J.D., 2008. Assessing the Effects of Climate Change on Aquatic Invasive Species. Conservation Biology, 22: 521-533. DOI: 10.1111/j.1523-1739.2008.00950.x.

Reise K., Olenin S., Thieltges D.W. 2006. Are aliens threatening European aquatic coastal ecosystems? Helgol. Mar. Res., 60: 77-83.

Rybczyk A., Szypula J. 2005. Age as well as length and weight growth of crucian carp from the Szczecin lagoon and the Leszczyńskie Lakeland. Electronic Journal of Polish Agricultural Universities. Series Fisheries, 8 (3).

Rybczyk, A.2006. Selected aspects of biological characteristics of the Prussian carp (Carassius auratus gibelio BLOCH, 1783): food, feeding, and condition. Acta Scientiarum Polonorum. Piscaria, 5 (2).

Solarz W. 2005. Aliens Species in Poland. Institute of Nature Conservation. Available: http://www.iop. krakow.pl/ias/Gatunek.aspx?spID=205 (October 2011).

Specziár A., Rezsu E.T. 2009. Feeding guilds and food resource partitioning in a lake fish assemblage: an ontogenetic approach. Journal of Fish Biology, 75: 247-267. DOI: 10.1111/j.1095-8649.2009.02283.x.

Witkowski A., Kotusz J., Przybylski M., 2009. The degree of threat to the freshwater ichthyofauna of Poland: Red list of fishes and lampreys - situation in 2009. Chrońmy Przyrodę Ojczysta, 65 (1): 33-52.

Wołos A., Draszkiewicz-Mioduszewska H. Mickiewicz M. 2014. Wielkość i charakterystyka jeziorowej produkcji rybackiej w 2013 roku. In: Zrównoważone korzystanie z zasobów rybackich na tle ich stanu w 2013 roku, M. Mickiewicz, A. Wołos (eds.). Wyd. IRS, Olsztyn, pp. 9-20.

Wouters J., Janson S., Luskova V., Olsen K.H. 2012. Molecular identification of hybrids of the invasive gibel carp Carassius auratus gibelio and crucian carp Carassius carassius in Swedish waters. J. Fish Biol., 80: 2595-2604.

Cite as: Panicz R., Keszka S., Rybczyk A., Zawal A. 2016. Molecular study of Prussian carp - an invasive species in the lakes of the Leszno Lakeland. Acta Biologica, 23: 47-54. DOI: 10.18276/ab.2016.23-04. 